\title{
Financing Public Broadcasting: Ways of Funds Formation Ukrainian Case
}

\section{Yasinevich Stanislav*}

National Academy for Public Administration under the President of Ukraine, Odessa Institute, Ukraine

\begin{abstract}
This article discusses the financing of public broadcasting. This issue is considered from the standpoint of independence of public broadcasting as an informational, educational, communicative source that serves civil society. In considering the sources of financing, we were guided by the experience and examples of the European Union countries, research in this field, identified the advantages and disadvantages of the sources of funds formation.

On the example of Ukraine considers the formation of public broadcasting and problems of formation of sources of financing. Given the national peculiarities of the formation of public broadcasting and contextual factors, the own vision of the structure of funding sources was proposed. It is suggested to use the complex approach to the formation of the structure of financing of public broadcasting. An example of many Western countries, where the basis of financing of broadcasting creates one source, cannot be used in Ukraine. Therefore, several sources of funding have been proposed to create conditions for the independent functioning of public broadcasting in Ukraine.
\end{abstract}

Keywords: Public Broadcasting; Public Broadcasting Financing; The Ukrainian Case of Public Broadcasting Funds

\section{Introduction}

The value of public broadcasting for the Society has three components: value for individuals, value for society as a whole, economic value - influence on the productivity of the commercial market [1]. The request for the implementation of the value of public broadcasting in the Ukrainian society arose in the last few years. It should be noted that the process of creating public broadcasting in Ukraine began in 1997 with the adoption of the Law of Ukraine "On the Public Television and Radio Broadcasting System of Ukraine". Political events in Ukraine influenced the adoption of the new version of the law in 2005. Only in 2014 the new Law of Ukraine "On Public Television and Radio Broadcasting" No. 1227 came into force. With the adoption of this law began a real formation of public broadcasting in Ukraine [2].

According to this Law, the "National Public Television and Radio Company" (National Public Broadcasting Company of Ukraine UA:PBC) was established on the basis of the National Television Company of Ukraine, the National Radio Company of Ukraine, the State Television and Radio Company "Kultura", the regional state Television and radio companies, the State Television and Radio Company "Crimea", the Kiev State Regional Television and Radio Company, the Sevastopol Regional State Television and Radio Company, other Television and radio companies and the Ukrainian studio of television films "Ukrtelefilm".

The Supervisory board manages Public broadcasting, and it is formed of the members of which are proposed by public organizations and political factions of the Verkhovna Rada (Parlament) of Ukraine (UA:PBC).

The founder of the UA:PBC is the State with a legal form of the entity - Public Joint Stock Company. Many scientific and public figures of Ukraine do not quite agree with the form of the founder and the form of a legal entity. The discussion continues in Ukraine on this issue. An important and controversial aspect remains the financing of public service broadcasting in Ukraine, to which we will like devote our research.

\section{Literature Review}

The functioning of public broadcasting puts many questions on the agenda. These questions constitute an array of discussions in several directions. It is possible to distinguish scientific discourse concerning the value of public broadcasting for society as a phenomenon in general $[3,4]$. Creating values for society as a product of public service broadcasting [5-7]. The problem of the activity of public broadcasting in the digital age [8-10]. The influence of politicians, government agencies and other actors on the ecology of public service broadcasting [11,12]. Close to our research is the scientific discourse on the functioning of public broadcasting in the conditions of the market behavior of subjects and state participation in this process $[9,13,14]$.

\section{Methods}

This research was prepared based on quantitative analysis of data from open sources. Secondary data laid the groundwork for reasoning. Secondary data are obtained from printed sources and electronic sources:

1. A group of printed sources consists of publications, books, scientific journals, articles, etc.

2. The group of electronic sources consists of online publications, websites, web portals, etc.

The main methods that allowed us to make some assumptions and conclusions were induction and deduction. Using these methods, we were able to analyze the cases of public broadcasting funds of European and other countries, as well as to identify the main sources of funding for public broadcasting in Ukraine.

The main object of the study is the functioning of public broadcasting. This study had an appropriate context, which is reflected

*Corresponding author: Yasinevich Stanislav, National Academy for Public Administration under the President of Ukraine, Odessa Institute, Ukraine, Tel: 095556 59440; E-mail: region.stas@gmail.com

Received August 16, 2018; Accepted September 26, 2018; Published October 03 , 2018

Citation: Stanislav Y (2018) Financing Public Broadcasting: Ways of Funds Formation Ukrainian Case. J Mass Communicat Journalism 8: 392. doi: 10.4172/2165-7912.1000392

Copyright: (c) 2018 Stanislav Y. This is an open-access article distributed under the terms of the Creative Commons Attribution License, which permits unrestricted use, distribution, and reproduction in any medium, provided the original author and source are credited. 
in the recognized principles of public broadcasting: independence, transparency, mission fulfillment, civil society service, etc. The subject of our research is ways of formation of public broadcasting funds in Ukraine. The main condition of this process is to ensure the aforementioned principles.

\section{Theoretical Background}

In our view, the problem of the formation of public broadcasting funds reflects two opposing viewpoints on this process. On the one hand, the researchers say that the public broadcaster is the market subject, the consumer, which is the financial basis of its activity, evaluates the result of its activity [9].

On the other hand, the researchers believe that by realizing their economic function, public broadcasting provides public goods to society. These goods are characterized by accessibility to all members of society, as well as non-exclusion of consumption. The non-exclusion of economic agents from the benefit is that they cannot be excluded from consumption through the establishment of market prices and cannot choose the volume of consumption. The financing of goods is based on the taxation of all members of society $[15,16]$.

It should be noted that the commercialization of various aspects of public life has contributed to criticism of the legitimacy and effectiveness of State actions as a supplier of goods and services in today's society. The attack on all non-commercials including public broadcasting is a consequence of the total adoption of the neo-liberal concept [17]. The concept insists that the market and commercial indicators are the best regulators of the activities of the media and all aspects of society.

Should be taken into account that one of the market mechanisms to finance the production of public goods is the subscription fee. There is also an opinion that the economically rational reluctance of people to voluntarily participate in the production of public goods requires the use of alternative mechanisms with regard to compensation for the cost of production of public goods [18].

Public investment in the production and distribution of public broadcasting is largely justified by the expectations substantial benefits social and cultural issues that accumulate in the society, and the benefits, which are both individuals and society as a whole. Thus, public media pays more attention to the needs of clients who act in the social role of citizens and voters, as opposed to the role of the consumer [19].

Free broadcasting is not competitive because the consumption of a broadcast program by one person does not prevent the consumption of others. Here we can talk about a new economy in the information sector that contradicts the main pillars of the market system: exclusive rights, rivalry, and transparency. According to De Long and Froomkin "New economy» - the economy of non-exclusion and not a rivalry [20]. Pay TV is the result of the old economy, it excludes potential users who could enjoy the goods and services that can be are offered at no additional cost.

It should be noted that the provision of broadcasting services should be considered within the framework of economic prerequisites that are reflected in the functioning of the economies of different countries. Goods and services in the media sector are provided by different types of institutions: the market where commercial broadcasters operate, government or state, non-governmental nonprofit organizations, public broadcasting. All of them have their advantages and disadvantages.

Markets ensure the creation of programs that are produced with economic efficiency, use innovations and meet consumers 'preferences.
However, there are market failures, in which case commercial products will deviate from the provision of optimum public welfare. The distributive of the market is determined by the customer's income, not taking into account the reasons of income differences or criteria of necessity, which may be relevant for the distribution of goods from an ethical, social or political point of view. In addition, it is necessary to take into account whose property is commercial media and what political viewpoint they protect. There is a question of journalistic ethics, pluralism, transparency, impartiality, etc. This issue is relevant for Ukraine and will be discussed below.

The government can provide goods with market failures and take into account its distributivity, take into account asymmetry, nonexclusion, etc. From a social standpoint, public broadcasting has a number of advantages, but there are also shortcomings. The economic efficiency of the state broadcasting is generally lower than that of commercial, it has no significant incentive to increase it, consumer preferences may not be considered. The political context always exists in the control of the state broadcasting, correspondingly the guarantees of activity and mechanisms of protection of the state broadcasters from various influence are necessary.

Non-governmental non-profit organizations confirm their name and can provide content without commercial or political dominance in programs. They combine commercial mechanisms of action and can have state financial support for their activities. The main disadvantage of this form of broadcasting is a non-representative form of broadcasting, which is aimed primarily at the members of the organization and the presentation of their opinion in the media sphere.

\section{Discussion}

The world community has accumulated considerable experience in the construction of models of public broadcasting and it's financing. For example, the Australian model provides for the financing of two nationwide $\mathrm{ABC}$ and $\mathrm{ABS}$ broadcasters, with appropriations specifically allocated by Parliament. This money is directed at operating expenses, broadcasting, development of digital television, an increase of capitalization [21].

One of the world's flagships of public broadcasting $\mathrm{BBC}$ is funded by a license fee received from the consumer. The public broadcasting system operates on a wide scale, providing consumers with services that legislatively defined the Parliament. With the exception of sports, in 2013, public broadcasters spent more than $£ 2$ billion on new content [22].

In general, the ways of financing public broadcasters differ between different countries of the world. There are differences in the type of funding provided, the extent of government funding, its per capita index, and the extent to which public broadcasters are able to attract viewers. The main sources of funding are public funds, licensing fees paid by Citizens for the services of the public broadcaster, commercial income from advertising and other activities. The study [23] shows that in 14 countries out of 31 considered, the main source of funding is a license fee paid by the citizens.

Financing the activities of public broadcasters remains a major challenge today and in the future. This will be a challenge for them, especially in the new economic realities. It will be necessary to continue to maintain funding from public funds and to revise public broadcasting management systems that can provide consumers more control through external management structures [24]. 
It is questionable that it is possible to rely only on public funding for public broadcasting. A review of the world experience of such financing shows that there are very large risks to the functioning of this model. For example, the functioning of the public channel "OTP" (Russia) began in June 2013 and was based on public money. In 2013, about 46.0 million dollars were financed. The same funds were planned for 2014 and 2015. But, already in 2013, it was determined that this amount covers only $65-70 \%$ of the funds necessary for the work of the public broadcaster. The channel was supposed to be funded also by donations from citizens, but in two months a very modest, small amount was received [25].

Problems of financial maintenance of functioning of public broadcasting also arise in the countries of the European Union. The report of the Council of Europe Commissioner for Human Rights cites some instances of such risks [26]. Here are some examples. In Poland, in 2016 the public media reform was carried out, as a result of which public television and radio came under direct control of the government, and the constitutional role of the media regulator was limited. This reform has already negatively influenced the freedom of media and the activities of journalists in particular. The list, compiled by the Independent Association of Journalists Society, shows that since the beginning of the last year 228 journalists of the public broadcaster have been released, or transferred to other posts, or resigned as a protest.

The problem of financing exists also in Romania, where in October 2016 parliament passed a law that liquidates more than 100 nontax levies, including a license fee on television and radio, which was the main source of funding for public Broadcasters. This step was severely criticized by journalistic organizations, as it would lead to the dependence of public media on the state budget, while the licensing system was considered as the best guarantee of editorial Independence of public media.

In Greece, in June 2013, the government unexpectedly decided to close the public broadcaster ERT as a measure to save costs. ERT continued to work on the Internet and, in the end, its broadcasting was restored in 2015. However, by liquidating, albeit temporarily, public media, the Greek authorities inflicted significant damage to pluralism in the country.

Currently, radio and television in Bosnia and Herzegovina (BHRT) are facing a similar threat and may be closed because there is no agreed plan for the sustainable financing of public media.

A similar situation has developed in Ukraine. According to the Law of Ukraine, on public broadcasting, financing goes to the provision of broadcasting of all channels of UA:PBC: 2 nationwide TV channels "UA: The first" and "UA Culture", satellite-cable TV channel "UA: Crimea", 3 nationwide radio channels UA: Ukrainian radio, Radio "Promin", Radio "Culture", 25 regional TV company in each area.

The widespread practice of revising expenditures financed from the General Fund of the State budget has resulted in a decrease in the number of public broadcasting resources in 2017. UA:PBC should receive from the budget 1.26 billion $\mathrm{UAH}$, however, in budget-2017 is only $75 \%$ of this amount by 309 million UAH less [27].

In the budget for 2018, the financial support of the national public broadcasting is laid only 776 million $\mathrm{UAH}$, which is twice less than the amount stipulated by the legislation, which was to be at least $0.2 \%$ of expenditures of the General Fund of the State budget of Ukraine for the previous year in 2018, which is not less than 1.54 billion UAH (Figure 1).

In the Ukrainian scientific and public discourse on the models of financing public service broadcasting, there is an opinion that it is necessary to make public media activities as non-commercial as possible. A funding structure is proposed that consists of three sources: a license fee; the state budget (subject to their allocation to a separate budget item); target deductions from commercial channels [28].

The license fee is a traditional source of funding for public television and can provide maximum financial autonomy to public media. In addition, it is necessary to note some more advantages of the license fee:

- The broadcasting organization does not depend on the political influence of the subjects, which determine the number of appropriations from the State budget.

- The creation of programs and the submission of political events do not necessarily coincide with the Government's wishes when allocating the necessary funds.

- The amount of revenue from the license fee may be more predictable than the appropriation from the State budget and may affect the accuracy of strategic planning and investment of public broadcasting.

We can say that the broadcasting organization becomes selfgoverning and independent of politicians and the government. There is also a kind of psychological connection between the citizen (which is paid by the license fee) and the public broadcaster, citizens are aware of the importance of independent broadcasting and can give an objective assessment to broadcasting.

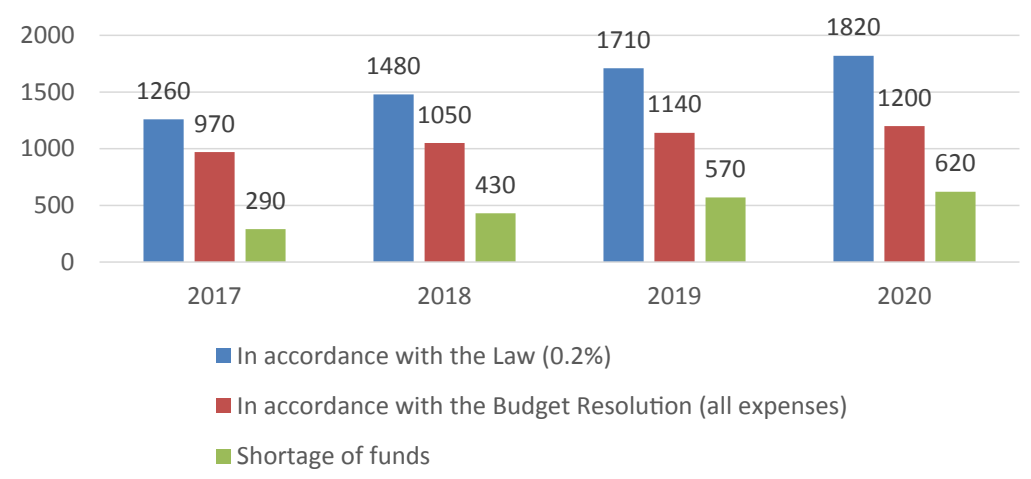

Figure 1: The amount of underfunding of public broadcasting in 2017-2020 (million UAH). 
For Ukraine, the issue of license fee remains open and complex. Studies of the European Audiovisual Observatory show that the introduction of a license fee in the CIS countries is postponed indefinitely and remotely. The basis for such an assertion is the lack of appropriate traditions and political culture, and the rapid development of commercial television has made the majority of the population clearly dependent on frivolous entertainment programs [29].

In the Ukrainian discourse, there is also an opinion that at the first stages it is impossible to do without the state financing, and also that the population is not ready to incur additional costs. We believe that people pay for public broadcasting as citizens while paying for public service broadcasting is paid directly, and not indirectly.

Another thorough sociological study was conducted by Kantar TNS in 2017 within the framework of the Council of Europe project "Strengthening of media freedom and creation of a public broadcasting system in Ukraine".

The study examined the audience, the level of satisfaction, the general level of trust and the level of confidence in the news provided by public broadcasting. In the format of the personal interview were interviewed 9600 respondents aged 18 years in 24 regions of the country, except for certain areas of Donetsk and Luhansk regions and Crimea.

The study showed that, depending on the region, only $17 \%$ of respondents agreed to pay for public broadcasting services. At the same time, the optimal cost of subscription of the package to public TV channels and radio is specified in $40 \mathrm{UAH}$ per month [30].

In addition, according to the research of TNS among all population of Ukraine, only $9 \%$ are ready to pay a license fee for public broadcasting in the amount from 25 to $65 \mathrm{UAH}$.

Another study was conducted by the foundation named Ilka Kucheriv "Democratic initiatives" together with the Kiev International Institute of Sociology from October 23 to November 5, 2017. 1614 respondents at the age of 18 years were interviewed in all regions of Ukraine, except Crimea and occupied territories of Donetsk and Luhansk regions. The theoretical error of sampling does not exceed $2.6 \%[31]$.

So, the question "Are you ready to pay up to $10 \mathrm{UAH}$ a month for the opportunity to watch/listen/read the objective and impartial news, analytics on the channels of public broadcasting about events in your area, Ukraine and the world? " the answer was received:

Definitely yes $12.8 \%$ Rather yes $16.9 \%$

\section{Rather no $24.4 \%$}

Definitely no $36.8 \%$

Hard to say $9.1 \%$.

It is necessary to make an important clarification for the overall picture of the subject of research. In Ukraine, during the formation of independence and the establishment of market relations, commercial broadcasting rapidly developed the number of channels and radio grew year after year. At the same time, state television did not receive the necessary financial means for appropriate competition, which led to the decline and irrelevance of the state broadcasting. The ether was filled with commercial media, well financed, provided with new equipment and new technologies.

In modern political, informational conditions both inside Ukraine and on the global scale, the population tries to find reliable information. Often media provide news, analytics, etc. within the political preferences of the channel owners and the political forces behind them [32]. In accordance with our expert opinion, a market of imperfect competition has developed in the media sphere in Ukraine. It follows that it is necessary to introduce another player who acts based on the principles of public service broadcasting and respects the appropriate media ecology.

Both the government and the parliament understand the complexity of the issue of introducing additional expenditures of the population. Scientific and public discourse also does not answer this question. There is a discussion of other sources of financing public service broadcasting.

It is proposed to finance public broadcasting at the expense of rent for the use of radio frequency resources. Analyzing the revenues of the State Budget, it was determined that there is tax revenue that can be logically linked to the costs of supporting the UA:PBC. Such a tax receipt is a rental fee for the use of the radio frequency resource of Ukraine. Users of radio frequency resources are television and radio broadcasters and representatives of telecommunications services; they are the payers of the monthly rent. Now all proceeds from this rental payment go to the general fund of the State budget, therefore, now there is no specific targeted interested recipient of these funds.

It is proposed to allocate $50 \%$ of this rental payment to a special fund of the State Budget and to ensure targeted use to support the UA:PBC (Figure 2).

We believe that the financing of public media should take place at the initial stage from the state budget with a gradual transition to the world's tested models. For this purpose, it is necessary for a certain time to form trust of the population to the public broadcaster, which

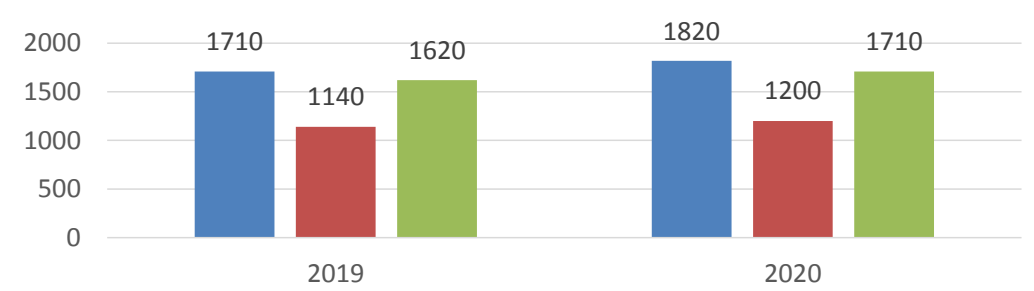

In accordance with the Law $(0,2 \%)$
Really planned funds in the Budget
$50 \%$ of rent for the use of radio frequency resources

Figure 2: Income from rent for use of radio frequency resource (million $U A H$ ). 
Citation: Stanislav Y (2018) Financing Public Broadcasting: Ways of Funds Formation Ukrainian Case. J Mass Communicat Journalism 8: 392. doi: 10.4172/2165-7912.1000392

Page 5 of 5

\begin{tabular}{|c|c|c|c|}
\hline No. & Source of Financial Income & $\begin{array}{c}\text { Percentage of Public } \\
\text { Broadcasting Requirements }\end{array}$ & Notes \\
\hline 1. & License fee & $25-60 \%$ & $\begin{array}{l}\text { This income item requires the gradual introduction and definition of the } \\
\text { mechanism for its collection }\end{array}$ \\
\hline 2. & State subsidies & up to $40 \%$ & $\begin{array}{l}\text { It is necessary to allocate this article to a special fund of the state budget } \\
\text { with the targeted use }\end{array}$ \\
\hline 3. & Rent for the use of radio frequency resources & up to $75 \%$ & $\begin{array}{c}\text { The introduction of this income item requires the support of Parliament } \\
\text { and changes in relevant laws }\end{array}$ \\
\hline 4. & A special tax on advertising commercial media & up to $10-15 \%$ & $\begin{array}{l}\text { Depends on the state of the market, it is difficult to predict the volume of } \\
\text { income, a mechanism for collecting taxes is necessary }\end{array}$ \\
\hline 5. & Sponsorship, voluntary donations, grants, etc. & up to $10 \%$ & It is hard to predict, it is impossible to include in the plans of action \\
\hline
\end{tabular}

Table 1: The structure of financing of national public broadcasting of Ukraine.

after some time will be financed by the subscription fee as a conscious civil act.

In the course of our research, we have come to certain conclusions and offer the structure of financing of national public broadcasting of Ukraine. In the course of political discussions and public discussion from the proposed structure, it is possible to create funds for financing public broadcasting in Ukraine (Table 1).

\section{Conclusions}

Today the Ukrainian public broadcasting is faced with many problems of becoming. This is political pressure, the need to replace obsolete equipment, which is left of the state broadcaster, improvement of management, the creation of competitive content, the attraction of professional journalists and much more. The process of the formation of public broadcasting in Ukraine differs significantly from the processes of commercialization of broadcasting in the countries of the West. In Ukraine, public broadcasting needs to win segments in the broadcasting market, in contrast to world examples of the establishment and commercialization of the media, where commercial broadcasters needed to win segments from the public broadcaster.

The emergence of public television in Ukraine has national and contextual features. Nevertheless, the question of financing is very important for ensuring the principles of the functioning of public broadcasting, the formation of civil society, a legal and democratic state. During the formation and reform of the economic, political and social system in Ukraine, the search for a reliable system for financing public service broadcasting will lay the foundation for independent service to society.

\section{References}

1. Ofcom (2004) Looking to the Future of Public Service Television Broadcasting, Ofcom Review of Public Service Television Broadcasting: Phase 2 (London: Office of Communications).

2. The Law of Ukraine (2014) "On Public Television and Radio Broadcasting".

3. Raboy M (1997) The World Situation of Public Service Broadcasting: Overview and Analysis.

4. O'Neill O (2015) What is public about Public Service Broadcasting? Concepts of public service broadcasting in a changing policy context.

5. Syvertsen T (1999) The Many Uses of the "Public Service".

6. Collins R (2007) The BBC and public value. Medien und Kommunikationswissenschaft 65: 164-184.

7. Rothbauer J, Gernot S (2013) Welfare Effects of Public Service Broadcasting in a Free-to-Air TV Market.

8. Kuhn R (1999) Public service broadcasting in the digital age: the British case.

9. Armstrong M (2005) Public Service Broadcasting. Fiscal Studies, 26: 281-299.
10. Ágnes Gulyás, Ferenc Hammer (2013) Public Service Media in the Digital Age: International Perspectives. Cambridge Scholars Publishing.

11. RISJ (2012) A Comparative Study of the Conflicts Between Public Service Broadcasting (PSB) and Governments in the UK and South Korea.

12. Humphreys $P$ (2014) A Comparative Study of Public Service Broadcasting under Pressure: Are we seeing the Triumph of Hallin and Mancini's Liberal Model?

13. Lowe GF, Bardoel J (2007) From Public Service Broadcasting to Public Service Media.

14. Nakamura Y (2009) Accountability in Public Service Broadcasting: The Evolution of Promises and Assessments.

15. Anderson S, Coate S (2000) Market Provision of Public Goods: The Case of Broadcasting. National Bureau of Economic Research.

16. Davies G (2004) The BBC and Public Value. The Social Market Foundation.

17. McChesney RW (2004) The mythology of commercial broadcasting and the contemporary crisis of public broadcasting.

18. Grinberg R, Rubinshtein A (2013) Individual \& State: an economic dilemma.

19. Brown A (1996) Public service broadcasting in four countries: Overview. The Journal of Media Economics 9: 77-81.

20. De Long JB, Michael Froomkin (1997) The Next Economy?.

21. ABC (2004) Annual report. The National Broadcaster.

22. Ofcom (2015) Public Service Broadcasting in the Internet Age. Ofcom's Third Review of Public Service Broadcasting.

23. CESifo DICE Report (2014) Public Service Broadcasting in an International Comparison.

24. Collins R, Finn A, McFadden S, Hoskins C (2005) Public Service Broadcasting Beyond 2000: Is There a Future for Public Service Broadcasting? Canadian Journal of Communication.

25. BBC (2013) "Public television of Russia "spent all the money.

26. Council of Europe (2017) Public service broadcasting under threat in Europe. The commissioner's human rights comments.

27. Detector Media (2018) New Model of Public Broadcasting Financing in Ukraine: How to Ensure Budgetary Stability of NSTU.

28. Bolschakova O (2008) Concerning the problem of financing public service broadcasting.

29. European Audiovisual Observatory (2006) Public Service Broadcasting Regulation in the Commonwealth of Independent States.

30. Council of Europe (2017) With the support of the Council of Europe, the largest sociological study of the audience of the Public Broadcasting was conducted.

31. Democratic Initiatives (2017) Reforms in Ukraine: what has not been completed and has not yet been implemented.

32. BBC (2017) TV-card of Ukraine 